\title{
Negative effects of long-term feeding of high-grain diets to lactating goats on milk fat production and composition by regulating gene expression and DNA methylation in the mammary gland
}

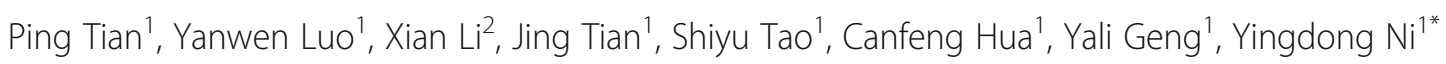
and Ruqian Zhao ${ }^{1}$

\begin{abstract}
Background: It is well known that feeding a high concentrate $(\mathrm{HC})$ diet to lactating ruminants likely induces subacute ruminal acidosis (SARA) and leads to a decrease in milk fat production. However, the effects of feeding a $\mathrm{HC}$ diet for long periods on milk fatty acids composition and the mechanism behind the decline of milk fat still remains poorly understood. The aim of this study was to investigate the impact of feeding a HC diet to lactating dairy goats on milk fat yield and fatty acids composition with an emphasis on the mechanisms underlying the milk fat depression. Seventeen mid-lactating dairy goats were randomly allocated to three groups. The control treatment was fed a low-concentrate diet ( $35 \%$ concentrate, $n=5, \mathrm{LC}$ ) and there were two high-concentrate treatments ( $65 \%$ concentrate, $\mathrm{HC}$ ), one fed a high concentrate diet for a long period (19 $\mathrm{wks}, n=7, \mathrm{HL}$ ); one fed a high concentrate diet for a short period of time ( $4 \mathrm{wk}, n=5$, HS). Milk fat production and fatty acids profiles were measured. In order to investigate the mechanisms underlying the changes in milk fat production and composition, the gene expression involved in lipid metabolism and DNA methylation in the mammary gland were also analyzed. (Continued on next page)
\end{abstract}

\footnotetext{
* Correspondence: niyingdong@njau.edu.cn

'Key Laboratory of Animal Physiology \& Biochemistry, Nanjing Agricultural

University, Nanjing 210095, People's Republic of China

Full list of author information is available at the end of the article
} 
(Continued from previous page)

Results: Milk production was increased by feeding the HC diet in the HS and HL groups compared with the LC diet $(P<0.01)$, while the percentage of milk fat was lower in the HL $(P<0.05)$ but not in the HS group. The total amount of saturated fatty acids (SFA) in the milk was not changed by feeding the HC diet, whereas the levels of unsaturated fatty acids (UFA) and monounsaturated fatty acids (MUFA) were markedly decreased in the HL group compared with the LC group $(P<0.05)$. Among these fatty acids, the concentrations of C15:0 $(P<0.01)$, C17:0 $(P<0.01), C 17: 1(P<0.01), C 18: 1 \mathrm{n}-9 \mathrm{c}(P<0.05), C 18: 3 \mathrm{n}-3 \mathrm{r}(P<0.01)$ and $C 20: 0(P<0.01)$ were markedly lower in the HL group, and the concentrations of $\mathrm{C} 20: 0(P<0.05)$ and $\mathrm{C18:3n-3r}(P<0.01)$ were lower in the HS group compared with the LC group. However, the concentrations of C18:2n-6c $(P<0.05)$ and C20:4n-6 $(P<0.05)$ in the milk fat were higher in the HS group. Real-time PCR results showed that the mRNA expression of the genes involved in milk fat production in the mammary gland was generally decreased in the HL and HS groups compared with the LC group. Among these genes, ACSL1, ACSS1 \& 2, ACACA, FAS, SCD, FADS2, and SREBP1 were downregulated in the mammary gland of the $\mathrm{HL}$ group $(P<0.05)$, and the expressions of ACSS2, ACACA, and FADS2 mRNA were markedly decreased in the HS goats compared with the LC group $(P<0.05)$. In contrast to the gene expression, the level of DNA methylation in the promoter regions of the ACACA and SCD genes was increased in the HL group compared with the LC group $(P<0.05)$. The levels of ACSL1 protein expression and FAS enzyme activity were also decreased in the mammary gland of the $\mathrm{HL}$ compared with the $\mathrm{LC}$ group $(P<0.05)$.

Conclusions: Long-term feeding of a $\mathrm{HC}$ diet to lactating goats induced milk fat depression and FAs profile shift with lower MUFAs but higher SFAs. A general down-regulation of the gene expression involved in the milk fat production and a higher DNA methylation in the mammary gland may contribute to the decrease in milk fat production in goats fed a $\mathrm{HC}$ diet for long time periods.

Keywords: DNA methylation, Gene expression, Goat, High concentrate diet, Milk fat,

\section{Background}

Milk contains high levels of nutrients such as proteins, fatty acids, phospholipids, vitamins and minerals [1]. Among these nutrients, milk fat plays an important role in determining the quality and energy composition of dairy products [2]. Milk fat contains large amount of saturated fatty acids (SFAs) and unsaturated fatty acids (UFAs). Recently, evidence has shown that high levels of SFAs pose a potential risk to human health such as cardiovascular disease (CVD) [3]. In contrast, there is epidemiological evidence suggesting that dietary monounsaturated fatty acids (MUFAs) and polyunsaturated fatty acids (PUFAs) have beneficial effects for preventing CVD by favorably affecting a number of risk factors for CVD, including plasma lipids and lipoproteins. For example, oleic acid has a protective effect against retinopathy [4]. Similarly, eico-sapentaenoic acid (EPA) and docosahexaenoic acid (DHA) play beneficial roles in preventing diabetes, atherosclerosis and arthritis [5]. Many strategies have been investigated to enhance the unsaturated fatty acid content of milk [6-8].

Milk triglycerides are derived from two sources: the biosynthesis of fatty acids and their subsequent esterification within the mammary gland and the uptake of lipids from plasma into the mammary gland [9]. Fatty acids in the mammary gland can also be generated by two pathways: short- and medium-chain fatty acids (C4-C14) can be synthesized de novo under the control of several key factors and enzymes including SREBP-1 (sterol regulatory element binding protein 1), ACACA (acetyl-coenzyme A carboxylase alpha), FAS (fatty acid synthase), and ACSS2 (acylCoA synthetase short-chain family member 2). Long-chain fatty acids $(C>16)$ are taken up from plasma via transporters such as fatty acid binding protein (FABP), fatty acid transport protein (FATP) and cluster of differentiation 36 (CD36) [10]. Acetate and 3-hydroxybutyrate are the main sources of a de novo synthesis for short-and medium-chain FAs [11]. These FAs in the mammary gland can be desaturated by stearoyl-CoA desaturase (SCD) and a synthesis of cis- 9 unsaturated FA and can then be esterified to glycerol sequentially via glycerol-3phosphate acyl transferase (GPAT), acyl glycerol phosphate acyl transferase (AGPAT), and diacylglycerol acyltransferase (DGAT) [11]; subsequently, the triglycerides are secreted into the milk as fat globules. The composition of milk fatty acids is highly variable and depends on several factors such as the animal breed, the lactating stage, the dietary lipids composition, the energy status, and the feeding regimes [12-14]. High levels of FAs are mobilized from adipose tissue in early lactation to provide more nutrients for the milk synthesis [12, 13]. In adipose tissue, fatty acids of $18: 1 \mathrm{c} 9,16: 0$, and 18:0 account for nearly $90 \%$ of total FAs [14] that are released into the blood during the negative energy balance of early lactation. These FAs are taken up through blood into the mammary gland and ultimately inhibit the de novo synthesis of fatty acids $[13,15]$. As a consequence, the concentration of short- and medium-chain FAs in milk is lower during the early lactation than the 
later lactation [13, 16]. However, it has been reported that during the early lactation, unsaturated fatty acids such as conjugated linoleic acid, linoleic acid, and omega-3 were enriched in the milk $[17,18]$.

Most dairy animals in intensive production systems are fed high levels of grain to maximize energy intake and milk production. However, excessive amounts of non-structural carbohydrates and highly fermentable forage will lead to a rapid fermentation and the accumulation of organic acids in the rumen [19], which likely induces subacute ruminal acidosis (SARA) $[19,20]$. Both acute and subacute ruminal acidosis can decrease the production of milk fat and cause milk fat depression and the shift of fatty acids profiles in lactating cows [20]. To our knowledge, the effects of longterm (more than $4 \mathrm{mo}$ ) feeding of a high concentrate (HC) diet to lactating ruminants on the production and composition of milk fat and the relevant mechanisms behind milk fat alterations are still unknown. In this study, mid-lactating dairy goats were fed a $\mathrm{HC}$ diet for a long (19 wk) or short (4 wk) period. Milk fat and FAs profiles were measured and the relevant gene expression and DNA methylation in the mammary gland were evaluated to investigate the mechanisms underlying the changes in milk fat production and composition.

\section{Methods}

\section{Animals and experimental procedures}

Seventeen healthy, mid-lactating goats (Guanzhong dairy goats, $60 \pm 5 \mathrm{~d}$ of lactation) with an average initial body weight of $49.7 \pm 5.5 \mathrm{~kg}$ (mean $\pm \mathrm{SD})$ and similar daily milk yield $(1.18 \pm 0.13 \mathrm{~kg} / \mathrm{d})$ were selected and housed individually (square measure: $3.0 \sim 3.2 \mathrm{~m}^{2}$ ) in a standard animal feeding house at Northwest A and F University (Shanxi, China). Prior to the experiment, all goats were allowed free access to a control diet containing a forage to concentrate ratio of 65:35 for 2 wk. Ingredients and chemical composition of the experimental diets were shown in the Additional file 1: Table S1. After dietary adaptation, goats were randomly assigned to three groups, and the daily milk yield in each group prior to the start of experiment did not show a significant difference as shown in Fig. $1(P>0.05)$. The control treatment was fed a low-concentrate diet (35\%concentrate, $n=5$, LC) while there were two high concentrate treatments $(65 \%$ concentrate, $\mathrm{HC})$, one fed a high concentrate diet for a long period ( $19 \mathrm{wk}, n=7, \mathrm{HL}$ ), and the other fed a high concentrate diet for a short period of time (4 wk, $n=5$, HS) after 15 wk of low concentrate diet. All goats were fed daily at 08:00 and 18:00, respectively, and milked twice daily before feeding.

\section{Sample collection and assay}

At the end of the experiment, goats were euthanized after overnight fasting. All goats were killed with neck

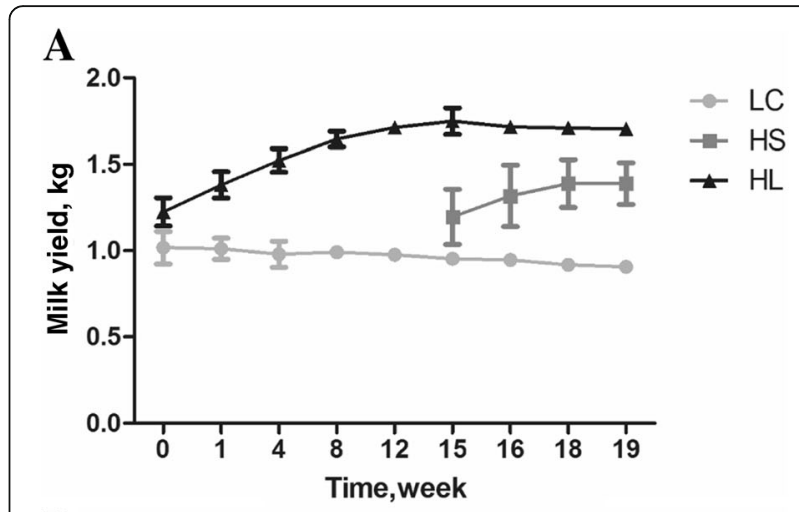

B
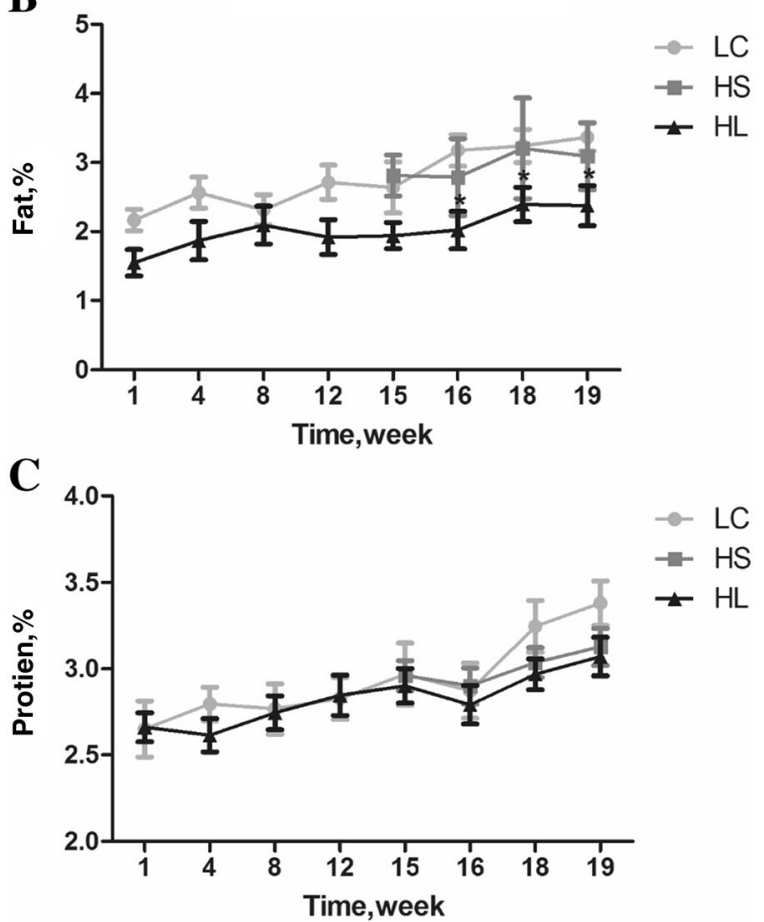

Fig. 1 The changes of milk yield, milk fat and protein. a Daily milk yield (kg/d); b Milk fat content (\%); c Milk protein content (\%). The asterisk * indicates a significant difference between $\mathrm{HL}$ and $\mathrm{LC}$ control group

vein injections of xylazine $[0.5 \mathrm{mg} / \mathrm{kg}$ body weight; Xylosol; Ogris Pharme, Wels, Austria] and pentobarbital [50 $\mathrm{mg} / \mathrm{kg}$ body weight; Release; WDT, Garbsen, Germany]. After euthanasia, a portion of mammary gland tissues were collected and immediately frozen in liquid nitrogen, and then used for total RNA, genomic DNA and protein extraction.

\section{Milk fatty acid analysis}

Milk samples were collected twice daily before feeding at 08:00 and 18:00, respectively. The samples of milk were mixed thoroughly, and one portion was stored at $4{ }^{\circ} \mathrm{C}$ for milk fat and protein analysis, another was stored at $-70{ }^{\circ} \mathrm{C}$ for fatty acids composition analysis. The level 
of milk fatty acids was detected following the standard protocol of gas chromatography in Jiangsu Academy of Agricultural Sciences as previously described [21].

\section{RNA extraction and real-time quantitative PCR}

Total RNA was extracted from each dairy goat using TRIZOL reagent (Takara, Dalian, China) according to the manufacturer's protocol, and total RNA concentration was then quantified by measuring the absorbance at $260 \mathrm{~nm}$ in a NanoDropND-1000 Spectrophotometer (Thermo Fisher Scientific, Madison, WI, USA). The quality of total RNA was also verified by electrophoresis. Then two micrograms of total RNA were treated with RNAse-Free DNase and reverse transcribed according to manufacturer's instructions (Takara, Dalian, China). The qRT-PCR efficiency was determined with serial 4-fold cDNA dilutions $(1,1 / 4,1 / 16,1 / 64,1 / 256$ cDNA template), and the efficiency was high with values between 95 and 100\%. Two microliter of diluted cDNA (1:16 vol/vol) was used for real-time PCR which was performed in Stratagene Mx3000P qPCR instrument (Agilent, California, USA). The information of primer sequence was shown in Table 1 . The mRNA expression of $18 S$ rRNA, $\beta$-actin and GAPDH genes was measured in the mammary gland tissues by real-time PCR, and GAPDH was finally used as a reference gene for normalization purpose due to the high efficiency and the stable expression in all samples. The method of $2^{-\Delta \Delta C t}$ was used to analyze the real-time PCR results and gene mRNA levels were expressed as the fold change relative to the mean value of control group [22].

\section{Western blotting analysis}

Frozen mammary gland $(100 \mathrm{mg}$ ) was minced and homogenized in $1 \mathrm{~mL}$ of ice-cold RIPA buffer ( $\mathrm{pH} 8.0$, $50 \mathrm{mmol} / \mathrm{L}$ Tris, $150 \mathrm{mmol} / \mathrm{L} \mathrm{NaCl}, 1.0 \%$ Triton X-100, $0.5 \%$ sodium deoxycholate, $0.1 \%$ SDS) containing a protease inhibitor cocktail (EDTA-free; $50 \times$ Conc.) (Roche Applied Science, Penz-berg, Germany). Then the homogenates was centrifuged for $20 \mathrm{~min}$ at $12,000 \times \mathrm{g}$ at $4{ }^{\circ} \mathrm{C}$. Protein concentrations were measured with a Pierce BCA Protein Assay Kit (No.23225, Thermo, USA). Sixty micrograms of protein extract from each sample were separated by electrophoresis in $7.5 \%$ or $10 \%$ SDS-PAGE, transferred onto nitrocellulose membrane (BioTrace, Pall Co, USA). After transferred, membranes were blocked for $2 \mathrm{~h}$ at room temperature in blocking buffer (3\% albumin from bovine serum), then incubated overnight at $4{ }^{\circ} \mathrm{C}$ with the following primary antibodies: rabbit anti-mouse $\alpha$-Tublin (Bioworld, BS1699 1:500), goat anti-mouse ACSL1 (santa cruz, sc-98,925, 1:200), goat anti-human SCD (santa cruz sc-23,016, 1:200). In western blot detection, $\alpha$-tublin was used as the internal control. Then the blots were incubated with the rabbit anti-goat horseradish peroxidase (HRP)-conjugated second antibody (E030130-01, Earth Ox, CA, 1:10,000) or goat anti-rabbit HRP-conjugated second antibody (Bioworld, BS13278, 1: 10,000) for $2 \mathrm{~h}$ at $25^{\circ} \mathrm{C}$, and the bound HRP activity was detected by use of VersaDoc Imaging System (Bio-Rad, CA, USA).

\section{DNA methylation assay}

Genomic DNA was extracted from mammary gland tissues using a commercial kit (DP304, TIANGEN Biotech Co., LTD. Beijing, China). In brief, $100 \mathrm{mg}$ mammary gland powder was incubated with $1 \mathrm{~mL}$ lysis buffer (pH 8.0, $50 \mathrm{mmol} / \mathrm{L}$ Tris; $100 \mathrm{mmol} / \mathrm{L}$ EDTA; $100 \mathrm{mmol} /$ L NaCl; $1.0 \%$ SDS) containing phenol, chloroform and $50 \mu \mathrm{L}$ proteinase $\mathrm{K}(10 \mathrm{mg} / \mathrm{mL}$ stock $)$ at $55^{\circ} \mathrm{C}$ for $2 \mathrm{~h}$, and then centrifugated at $12,000 \times \mathrm{g}$ for $5 \mathrm{~min}$. About $500 \mu \mathrm{L}$ supernatant was collected, and incubated with $500 \mu \mathrm{L}$ isopropyl alcohol and $60 \mu \mathrm{L} 3.0 \mathrm{~mol} / \mathrm{L}$ sodium acetate (pH 5.2) at room temperature for $5 \mathrm{~min}$, and then centrifugated at 12,000 rpm for $15 \mathrm{~min}$. The pellet was washed twice with 70\% ethanol, after drying the pellet was finally resuspended in TE buffer $(\mathrm{pH} 8.0,10 \mathrm{mmol} / \mathrm{L}$ Tris, $1 \mathrm{mmol} / \mathrm{L}$ EDTA). Samples were incubated at $65{ }^{\circ} \mathrm{C}$ in a shaking water bath for $1 \mathrm{~h}$ to ensure a good resuspension.

The isolated genomic DNA was sonicated to produce random fragments with the size from 300 to $500 \mathrm{bp}$. The sonication condition was set up with the following parameters: output power $30 \mathrm{~W}, 5 \mathrm{~s}$ pulse on and $5 \mathrm{~s}$ pulse off, 10 cycles. Two microgram of sonicated genomic DNA was heat-denatured to produce singlestranded DNA, and the same portion of the undenatured DNA was stored as control (input) DNA. The methylated DNA fragments was immune-precipitated by the mouse monoclonal antibody against 5-methyl cytidine (ab10805, Abcam). Precleared Protein A/G Plus Agarose (Santa Cruz, Dallas, TX) was used to immuneprecipitate the antibody/DNA complexes, and the MeDIP DNA was purified. Forty nanogram of MeDIP DNA and control input DNA was used to amplify the $A C A C A, S C D, F A S, A C S L 1, A C S S 1$ \& 2, FADS2 promotor regions by real-time PCR with specific primers (Table 2). The primers were designed with the software of "Methyl Primer Express" using the specific promotor sequence enriched with $\mathrm{CpG}$ sites blasted from the website of "http://www.ensembl.org/index.html". The ratios of the signals in the immunoprecipitated DNA vs input DNA were calculated as a measure for representing the relative enrichment of methylation in the particular sample.

\section{FAS enzyme activity assay}

FAS enzyme activity in mammary gland tissues was measured by FAS activity Assay Kit (jiancheng Bioengineering Institute, Nanjing, China). 
Table 1 PCR primer sequences of the target genes

\begin{tabular}{|c|c|c|c|}
\hline Target genes & Primer sequences & GenBank accession No. & PCR products, bp \\
\hline \multirow[t]{2}{*}{$L P L$} & F:5'-CAAGTCGCCTITCTCCCGAT-3' & NM_001285607.1 & 177 \\
\hline & R:5'-CTGCAATCACACGGAGAGCTT-3' & & \\
\hline \multirow[t]{2}{*}{ ACACA } & F:5'-TATGACGGCAGCAGTTACACC-3' & XM_018064168.1 & 201 \\
\hline & R:5'-CACCTCGATCTCAGCATAGCAC-3' & & \\
\hline \multirow[t]{2}{*}{ FAS } & F:5'-CCCCAAGCTCTTTGACAACCG-3' & NM_001285629.1 & 100 \\
\hline & R:5'-CAGCTCCTTGTACACGTCACC-3' & & \\
\hline \multirow[t]{2}{*}{ FABP3 } & F:5'-TGAGACCACGGCAGATGA-3' & NM_001285701.1 & 230 \\
\hline & R:5'-TAGCCCACTGGCAGAAGA-3' & & \\
\hline \multirow[t]{2}{*}{ FABP4 } & F:5'-CATAAACTTAGATGAAGGTGCTC-3' & NM_001285623.1 & 116 \\
\hline & R:5'-CACCGTTCATGACACATTCCA -3' & & \\
\hline \multirow[t]{2}{*}{ DGAT1 } & F:5'-AAGCCCTTCAAGGACATG-3' & XM_018058728.1 & 100 \\
\hline & R:5'-AGAGCCAGTAGAAGAAGATG-3' & & \\
\hline \multirow[t]{2}{*}{ CPT1B } & F:5'- CCAGCCACAGTTCATCGGTA-3' & XM_018048994.1 & 103 \\
\hline & R:5'-CAGTCTTCTCCTCGAACTCC-3' & & \\
\hline \multirow[t]{2}{*}{ ACSS1 } & F:5'-TGAGCGACTGCGACTTCC-3' & XM_018057282.1 & 223 \\
\hline & R:5'-CGGCGGACTCCATACCTCT-3' & & \\
\hline \multirow[t]{2}{*}{ ACSS2 } & F:5'-TGAGCCAGAGGAAACCA-3' & XM_005688483.3 & 157 \\
\hline & R:5'-ACACGCCAGCATAGCC-3' & & \\
\hline \multirow[t]{2}{*}{ ACSL1 } & F:5'-CGCAGTGGCATCATTAG-3' & XM_018041881.1 & 183 \\
\hline & R:5'-CTCGGTCTGTCCGTAGC-3' & & \\
\hline \multirow[t]{2}{*}{ SREBP1 } & F:5'-ACGCCATCGAGAAACGCTAC-3' & NM_001285755.1 & 181 \\
\hline & R:5'-GTGCGCAGACTCAGGTTCTC-3' & & \\
\hline \multirow[t]{2}{*}{ PPARY } & F:5'-CCTTCACCACCGTTGACTTCT-3' & NM_001285658.1 & 145 \\
\hline & F:5'-GATACAGGCTCCACTTTGATTGC-3' & & \\
\hline \multirow[t]{2}{*}{ CD36 } & F:5'-ATAATACTGCGGATGGA-3' & NM_001285578.1 & 165 \\
\hline & R:5'-TCTCAACGAAAGGTGG-3' & & \\
\hline \multirow[t]{2}{*}{$L D L R$} & F:5'-GTGGCTGACACCAAAGGG-3' & XM_005682375.3 & 175 \\
\hline & R:5'-CGGTCACCAGCGAGTAAAT-3' & & \\
\hline \multirow[t]{2}{*}{$S C D$} & F:5'-GTGGGTTGGCTGCTTG-3' & NM_001285619.1 & 243 \\
\hline & R:5'-CCAGGTGGCATTGAGC-3' & & \\
\hline \multirow[t]{2}{*}{ FADS2 } & F:5'-GCATCGCCTGGTTCACT-3' & XM_018043056.1 & 249 \\
\hline & R:5'-GGAAGATGTTGGGTTTGG-3' & & \\
\hline \multirow[t]{2}{*}{ GAPDH } & F:5'-GGGTCATCTCTCTGCACCT-3' & XM_005680968.3 & 176 \\
\hline & R:5'-GGTCATAAGTCCCTCCACGA-3' & & \\
\hline
\end{tabular}

\section{Statistical analysis}

All data are presented as the mean \pm SEM. The data of milk yield and milk composition was analyzed for differences due to diet treatment, time effect, and their interaction by using PROC MIXED, SAS 9.3, (SAS Institute Inc., Cary, NC, USA). The data of milk yield, milk fat and protein obtained before the beginning of the treatment was considered as a co-variable in the statistical analysis. The differences of parameters in fatty acids composition, gene and protein expression, enzyme activities in mammary gland were analyzed by using the post hoc analysis with the least significant difference test following ANOVA of SPSS 11.0. The $2^{-\Delta \Delta \mathrm{Ct}}$ method was applied to analyze the real-time PCR data. Differences were considered significant at $P<0.05$, and $0.05<P<0.1$ is considered as a tendency. Numbers of replicates used for statistics are noted in the Tables and Figures.

\section{Results}

Milk yield and production of milk protein and fat

As shown in Fig. 1a-c, goats fed a high concentrate diet (HL and HS group) produced $(P<0.01)$ more milk than 
Table 2 PCR primer sequences using for MeDIP

\begin{tabular}{|c|c|c|c|}
\hline Target genes & MeDIP primer sequence & GenBank accession No. & PCR products, bp \\
\hline \multirow[t]{2}{*}{ FADS2 } & F:5'-GGCACTAATCCCAAGCAG-3' & XM_018043056.1 & 138 \\
\hline & R:5'-GGAAACAATACAGGACCTCATA-3' & & \\
\hline \multirow[t]{2}{*}{ ACSL1 } & F:5'-GGGAGGCGAGCAGAAAGA-3' & XM_018041881.1 & 142 \\
\hline & R:5'-AACAGACGGTGGAGGGTG-3' & & \\
\hline \multirow[t]{2}{*}{ ACSS1 } & F:5'-ACCTGAGAAGGGATGTGG-3' & XM_018057282.1 & 104 \\
\hline & R:5'-AGAAGACTCAACGCAAACA-3' & & \\
\hline \multirow[t]{2}{*}{ FAS } & F:5'-TTGCCTAAAGTCAGTGTCG-3' & NM_001285629.1 & 169 \\
\hline & R:5'-GCAGGTCAACCGCATAAC-3' & & \\
\hline \multirow[t]{2}{*}{$A C A C A$} & F:5'-GCTITCTTCACCGAGGCT-3' & XM_018064168.1 & 173 \\
\hline & R:5'-CGGAGGGTATCGCATTCA-3' & & \\
\hline \multirow[t]{2}{*}{ ACSS2 } & F:5'-CCTCCCGTTCTGCTTTCC-3' & XM_005688483.3 & 132 \\
\hline & R:5'-AGCCGTGCCTGGTGGTGTTG-3' & & \\
\hline \multirow[t]{2}{*}{$S C D$} & F:5'-CCCCAGTGCCCATCCATTT-3' & NM_001285619.1 & 168 \\
\hline & R:5'-TCCCTTTCTCCTCGGCTTCTC-3' & & \\
\hline
\end{tabular}

goats fed a low concentrate diet (LC). Diet significantly affected the milk fat production $(P<0.05)$. The percentage of milk fat decreased in the HL group after 16 wk and was significantly different from the control group (LC) $(P<0.05)$, while the protein was not significantly affected by dietary treatment.

\section{Milk fatty acid composition}

The composition of the milk fatty acids was analyzed and is shown in Table 3. Compared with the LC group, the HL group exhibited a lower level of unsaturated fatty acids (UFA) and monounsaturated fatty acids (MUFA) in the milk $(P<0.05)$, while there was no significant difference between the LC and HS groups $(P>0.05)$. The content of saturated fatty acids (SFA) in the milk showed a tendency to increase in the HL group compared with the LC group $(0.05<P<0.1)$. Compared with LC, the concentration of C15:0 $(P<0.01), \mathrm{C} 17: 0(P<0.01), \mathrm{C} 17: 1$ $(P<0.01)$, C18:1n-9c $(P<0.05)$, C20:0 $(P<0.01)$ and C18:3n-3r $(P<0.01)$ in the milk was markedly lower in the HL group and the concentrations of C20:0 $(P<0.05)$ and $\mathrm{C} 18: 3 \mathrm{n}-3 \mathrm{r}(P<0.01)$ were lower in the HS group. Moreover, the contents of C18:2n-6c $(P<0.05)$ and C20:4n-6 $(P<0.05)$ in the milk were higher in the HS compared with the LC group.

\section{Gene expression involved in milk fat production}

As shown in Fig. 2, feeding a $\mathrm{HC}$ diet to lactating dairy goats down-regulated gene expression involved in milk fat production in the mammary gland. With respect to the fatty acid transport process, the mRNA expressions of the LPL, ACSL1, ACSS1 and ACSS2 genes were lower in the mammary gland of the HL goats $(P<0.05)$ and the CD36 and ACSS2 mRNA expressions were lower in
Table 3 Fatty acids composition in the milk fat

\begin{tabular}{|c|c|c|c|}
\hline Fatty acids & LC & $\mathrm{HS}$ & $\mathrm{HL}$ \\
\hline C4:0 & $0.78 \pm 0.05$ & $0.79 \pm 0.06$ & $0.91 \pm 0.08$ \\
\hline C6:0 & $1.19 \pm 0.06$ & $1.16 \pm 0.08$ & $1.27 \pm 0.11$ \\
\hline C8:0 & $1.45 \pm 0.08$ & $1.38 \pm 0.10$ & $1.48 \pm 0.14$ \\
\hline C10:0 & $7.27 \pm 0.29$ & $6.48 \pm 0.39$ & $7.23 \pm 0.55$ \\
\hline C11:0 & $0.13 \pm 0.03$ & $0.09 \pm 0.02$ & $0.09 \pm 0.01$ \\
\hline C12:0 & $4.72 \pm 0.36$ & $3.78 \pm 0.39$ & $4.69 \pm 0.45$ \\
\hline C13:0 & $0.09 \pm 0.01$ & $0.07 \pm 0.02$ & $0.10 \pm 0.03$ \\
\hline C14:0 & $12.15 \pm 0.38$ & $10.28 \pm 0.49$ & $11.30 \pm 0.6$ \\
\hline C14:1 & $0.24 \pm 0.02$ & $0.22 \pm 0.08$ & $0.21 \pm 0.04$ \\
\hline C15:0 & $1.22 \pm 0.05^{a}$ & $0.91 \pm 0.13^{\mathrm{ab}}$ & $0.85 \pm 0.06^{b}$ \\
\hline C15:1 & $0.17 \pm 0.08$ & $0.04 \pm 0.00$ & $0.10 \pm 0.03$ \\
\hline C16:0 & $33.16 \pm 1.90$ & $33.89 \pm 0.49$ & $38.19 \pm 1.8$ \\
\hline C16:1 & $1.31 \pm 0.07$ & $1.35 \pm 0.26$ & $1.18 \pm 0.08$ \\
\hline C17:0 & $0.93 \pm 0.02^{a}$ & $0.81 \pm 0.09^{a b}$ & $0.74 \pm 0.02^{b}$ \\
\hline C17:1 & $0.29 \pm 0.05^{\mathrm{a}}$ & $0.31 \pm 0.03^{\mathrm{ab}}$ & $0.22 \pm 0.22^{b}$ \\
\hline C18:0 & $7.01 \pm 0.69$ & $7.29 \pm 1.13$ & $6.32 \pm 0.57$ \\
\hline C18:1n-9c & $20.71 \pm 0.72^{a}$ & $22.80 \pm 1.06^{\mathrm{a}}$ & $18.17 \pm 0.51^{b}$ \\
\hline$C 18: 2 n-6 t$ & $0.12 \pm 0.01$ & $0.17 \pm 0.01$ & $0.14 \pm 0.01$ \\
\hline$C 18: 2 n-6 c$ & $1.96 \pm 0.12^{b}$ & $2.39 \pm 0.08^{\mathrm{a}}$ & $1.93 \pm 0.05^{b}$ \\
\hline$C 18: 3 n-3 r$ & $0.22 \pm 0.02^{a}$ & $0.12 \pm 0.01^{b}$ & $0.10 \pm 0.00^{b}$ \\
\hline C20:0 & $0.21 \pm 0.01^{a}$ & $0.17 \pm 0.01^{b}$ & $0.15 \pm 0.01^{b}$ \\
\hline$C 20: 4 n-6$ & $0.14 \pm 0.01^{b}$ & $0.18 \pm 0.01^{\mathrm{a}}$ & $0.14 \pm 0.01^{b}$ \\
\hline$\Sigma S F A$ & $68.39 \pm 1.03$ & $67.10 \pm 1.35$ & $73.34 \pm 0.65$ \\
\hline UFA & $25.26 \pm 0.94^{\mathrm{a}}$ & $27.58 \pm 1.36^{\mathrm{a}}$ & $22.21 \pm 0.60^{b}$ \\
\hline ¿MUFA & $22.79 \pm 0.83^{a}$ & $24.71 \pm 1.29^{a}$ & $19.89 \pm 0.58^{b}$ \\
\hline ¿PUFA & $2.47 \pm 0.13^{b}$ & $2.87 \pm 0.10^{a}$ & $2.32 \pm 0.05^{b}$ \\
\hline
\end{tabular}

Values are means \pm SE. Mean values without common superscript $(a, b)$ differ significantly among LC, HS and HL groups $(P<0.05)$ 

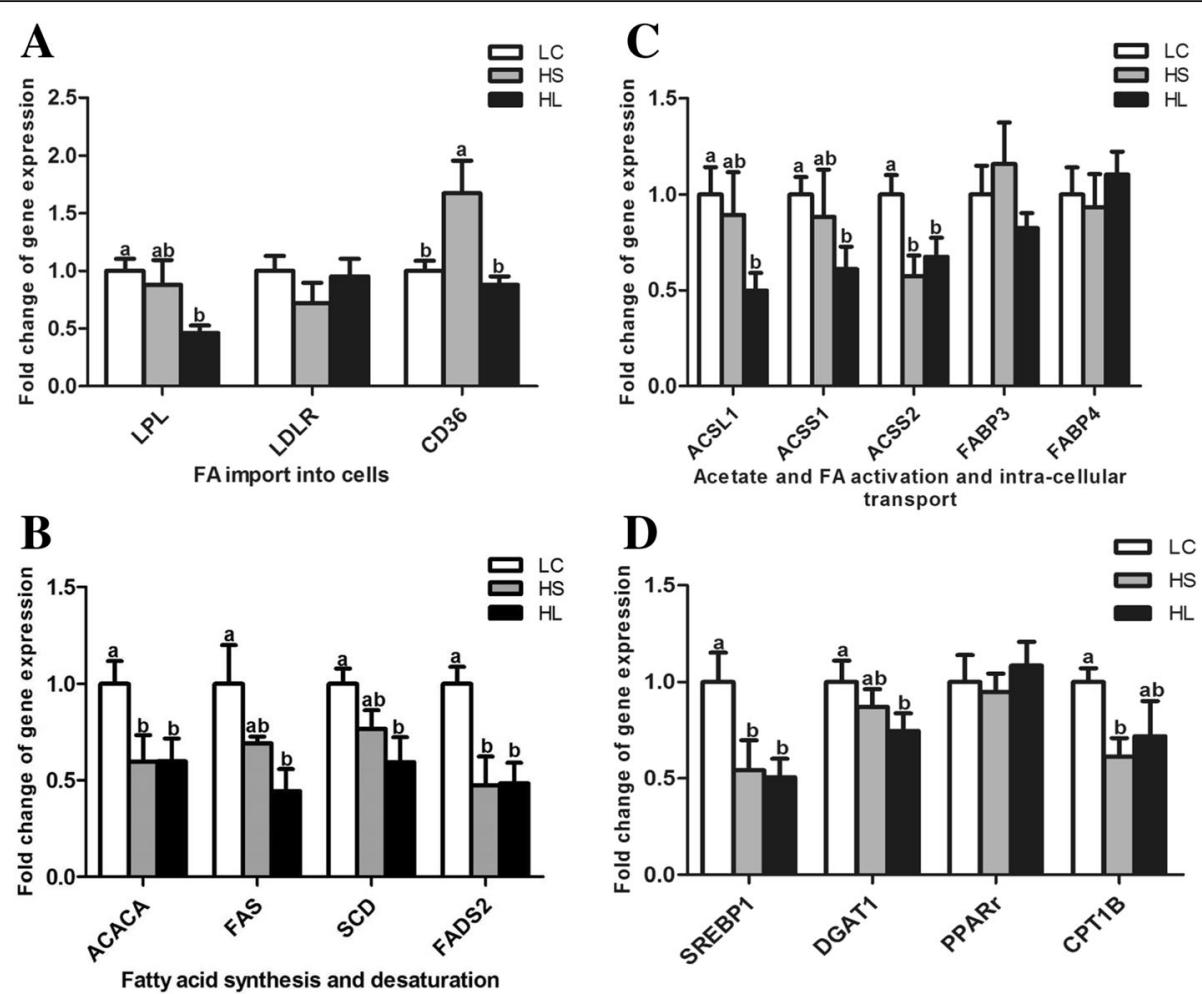

Fig. 2 Genes expression involved in milk fat production in the mammary gland. a mRNA expression of genes involved in FAs up-take; $\mathbf{b}$ mRNA expression of genes regulating FAs synthesis and desaturation; $\mathbf{c}$ mRNA expression of genes for FAs activation and transport; $\mathbf{d}$ mRNA expression of genes involved in TG synthesis. Data are presented as mean \pm SE. Mean values without common superscript $(\mathbf{a}, \mathbf{b})$ differ significantly among $L C, H S$ and $H L$ groups $(P<0.05)$

the HS group compared with the LC group $(P<0.05)$. The expressions of the genes involved in fatty acids synthesis and desaturation including SREBP-1, FAS, $A C A C A, S C D, F A D S 2$, and DGAT1 were also downregulated in the HL goats $(P<0.05)$ and the mRNA expressions of ACACA, FADS2, SREBP-1, and CPT1B were lower in the HS group compared with the LC group $(P<0.05)$. However, the levels of the PPAR- $\gamma$, $L D L R, F A B P-3$ and $F A B P-4$ mRNA expressions were not changed by feeding a $\mathrm{HC}$ diet $(P>0.05)$.

\section{Protein expression and FAS enzyme activity}

The levels of the ACSL1 and SCD protein expressions in the mammary gland were determined by western blotting. The results showed that the level of ACSL1 protein expression in the mammary gland was decreased by feeding a HC diet $(P<0.05)$, while the SCD protein expression was not altered $(P>0.05)$. The activity of the FAS enzyme was also decreased in the HL goats compared with the LC group $(P<0.05)$ and there was no significant difference between the HS and LC groups $(P>0.05)$ (Fig. 3$)$.

\section{DNA methylation analysis}

Due to a decrease in the gene expression involved in milk fat production in the mammary gland, the level of
DNA methylation in the promoter regions of the encoding genes was measured using the MeDIP method. The results showed that the DNA methylation in the promoter regions of the $S C D$ and $A C A C A$ genes was greater in the mammary gland of the HL goats compared with the LC group $(P<0.05)$. However, the levels of DNA methylation in the promoters of the ACSL1, ACSS1 \& 2, $F A S$ and FADS2 genes were not changed in the $\mathrm{HC}$ goats compared with the LC group $(P>0.05)$ (Fig. 4).

\section{Discussion}

To meet the energy demand of high milk production, dairy animals are commonly fed a HC diet, which likely causes abnormal fermentation in the rumen and leads to metabolic disorders known as SARA. Previous studies have shown that $19 \%$ of early lactation and $26 \%$ of midlactation cows experienced SARA [23]. Lactating animals suffering from SARA have increased risks for diarrhea, laminitis and inflammatory responses [24, 25]. This extensively-used feeding strategy ultimately leads to a decrease in milk quality with a lower quantity of milk fat [25-27]. In this study, as found in practice, our results showed that milk production was significantly increased by feeding a $\mathrm{HC}$ diet in both the $\mathrm{HL}$ and $\mathrm{HS}$ groups compared with the LC group, while the percentage 


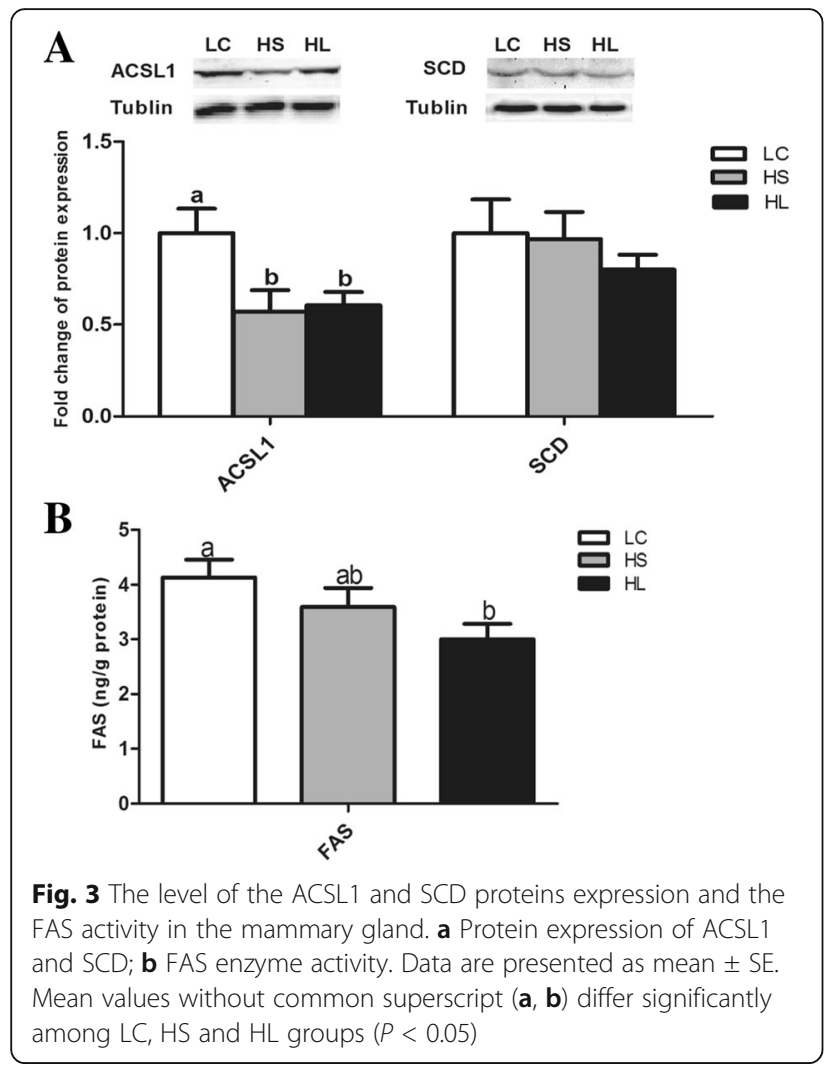

of milk fat was significantly lower in the HL group. A previous study also demonstrated that feeding high grain diets to lactating dairy cows led to milk fat depression with lower milk fat concentrations [28].

Milk and dairy products contain fatty acids with high proportions of SFA and MUFA and small amounts of PUFA $[29,30]$. Research has shown that humans consuming an excess of SFA have increased risk for coronary heart disease [31]. In contrast, UFAs benefit human health $[4,5]$. Chilliard et al. observed that high-quality alfalfa hay-based diets can increase the level of C18:3n-3

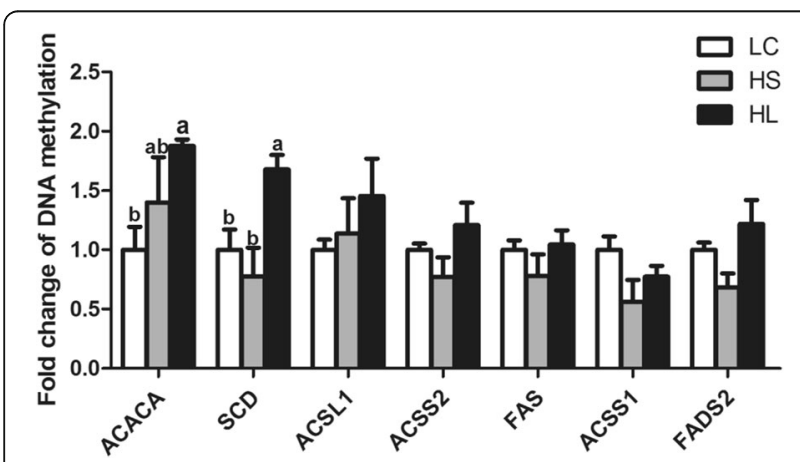

Fig. 4 The level of the DNA Methylation in the promoter regions of the target genes. Data are presented as mean $\pm \mathrm{SE}$. Mean values without common superscript (a, b) differ significantly among LC, HS and $\mathrm{HL}$ groups $(P<0.05)$ in the milk of dairy cows [32]. However, cows fed a high starch diet experienced milk fat depression syndrome [28]. A low milk fat content has even been suggested as a noninvasive indicator to identify cows with a greater risk for SARA [33]. Previous studies have shown that lactating ruminants with SARA induced by feeding a HC diet did not experience altered concentrations of SFAs, PUFAs or MUFAs in the milk but had markedly decreased concentrations of C18:2n:6c, C18:3n3, and C20:3n6 [27, 34]. Our results showed that the concentrations of C18:1n-9c, SFAs and MUFAs were not significantly changed by feeding a short-term $\mathrm{HC}$ diet in the HS group as reported in a previous study [27]. However, it is very important to note that long-term feeding of a $\mathrm{HC}$ diet significantly decreased the percentage of milk fat and the concentrations of UFAs and MUFAs, while the concentration of SFAs exhibited an increasing tendency in the milk compared with the LC control goats.

Fatty acid synthesis is a complex process including uptake, transport, synthesis and oxidation of fatty acids. With respect to the FAs uptake, LPL is an important enzyme in the mammary gland responsible for taking up long-chain fatty acids from albumin-bound fatty acids, lipoproteins, or chylomicrons [35]. LPL also can hydrolyze triglyceride (TAG) in lipoprotein core and then deliver fatty acids to the mammary gland for milk fat synthesis [36]. The HL goats showed a significant decrease of the LPL mRNA expression in the mammary gland compared with the LC group as reported previously [34]. SREBP1 and PPAR $\gamma$ are important transcription factors involved in milk fat synthesis $[37,38]$ and the lipogenic genes including ACACA, FAS, ACSL1, and $S C D$ are all target genes of SREBP1 in bovine mammary epithelial cells [39, 40]. Our results showed that the SREBP1 mRNA expression and its target downstream genes were significantly decreased in the mammary gland of the HS and HL groups compared with the LC group, while the PPARY gene expression was not changed. Moreover, short- and medium-chain FAs (C4-C14), as well as some portions of the C16 FAs, are mainly synthesized de novo in the mammary gland [41]. ACACA is the rate-limiting enzyme involved in the FAs de novo synthesis by controlling the production of short chain fatty acid (SCFA) and palmitic from acetate [42]. Fatty acid synthase (FAS) is a multifunctional protein that can catalyze the majority of the enzymatic steps in the fatty acid synthesis [43]. In the present study, we found that, in conjunction with the decrease in total milk fat percent and some specific FAs concentrations including C15:0, C17:0, C17:1, C18:1n-9c, C20:0 and C18:3n-3r, the mRNA expressions of the ACACA and FAS genes and the enzyme activity of FAS were significantly downregulated in the mammary gland of the HL goats. Therefore, it is reasonable to speculate that the decrease in the gene 
expression and enzyme activity responsible for the FAs synthesis in the mammary gland may contribute to milk fat depression in HL goats.

As a desaturase, SCD is an important enzyme for controlling the intracellular FAs composition by catalyzing the conversion of SFA into monounsaturated FAs [44, 45]. In this study, we found that the $S C D$ gene expression was significantly downregulated in the HL group, which may be responsible for the decrease in C18:1n-9c and the MUFA concentration in the milk of HL goats. Long-chain fatty acids were activated by acyl-CoA synthetase via long-chain family member isoforms (ACSL) [46], while short-chain fatty acids were activated by acyl-CoA synthetase shortchain family members (ACSS) [47]. ACSL1 is a predominant enzyme among the ACSL isoforms in the bovine mammary gland [48]. CD36 is another important enzyme controlling the long chain FAs uptake working in conjunction with intracellular fatty acidbinding proteins (FABP) [49, 50]. ACSS1 \& 2 mainly regulate the oxidative pathway of lipids and acetate activation, respectively $[47,51]$. In the present study, our results showed that the ACSL1 protein expression was also significantly decreased in the HL group compared with the LC group. The ACSS2 mRNA expression was also markedly decreased in the HL goats. These results indicate a potential decrease in the milk fat synthesis in the mammary glands of HL goats compared with their LC counterparts.

Epigenetic modifications are involved in regulating gene transcription [52]. DNA methylation is perhaps the most extensively studied epigenetic modification and plays an important role in the regulation of gene expression [53]. For decades, methylation has been believed to play a crucial role in repressing gene expression through blocking the promoter region where the activating transcription factors should bind [54]. With respect to the general downregulation of the gene expression involved in the milk fat synthesis in the mammary gland, the status of the DNA methylation in the promoter regions of the target genes has been analyzed as previously described [51, 54]. The results demonstrated that the methylation of the $S C D$ and $A C A C A$ promoters was significantly increased in the HL group compared with the LC group, which was consistent with the decrease in their gene expression. Consistently, previous studies also showed that the methylation in the $S C D$ promoter region was increased in dairy goats and cows fed a highconcentration diet [54]. However, the methylation in the promoter regions of $F A S, A C S L 1, A C S S 1, A C S S 2$, and FADS2 DNA was not changed by feeding a HC diet. We speculate that the modification of the DNA methylation was involved in regulating the milk fat depression in the HL goats. In contrast, the DNA methylation in the lipogenic genes promoter was not significantly altered in the mammary gland of the HS goats compared to the LC group. To date, no information has been provided for explaining the difference in the DNA methylation between the HS and HL groups. Moreover, the mechanisms behind the changes in DNA methylation in the HL goats still require further investigation.

\section{Conclusions}

Short-term feeding of a $\mathrm{HC}$ diet had minor effects on milk fat production and composition in lactating dairy goats. However, long-term feeding of a $\mathrm{HC}$ diet will induce milk fat depression and a FAs profile shift with lower MUFAs but higher SFAs. A downregulation of the gene expression involved in the process of lipid production and the upregulation of the DNA methylation in the mammary gland may contribute to the decrease in milk fat production in HL goats.

\section{Additional file}

Additional file 1: Table S1. Ingredients and composition of the experimental diets (\%). (DOCX $13 \mathrm{~kb}$ )

\section{Abbreviations}

ACACA: Acetyl-coenzyme A carboxylase alpha; ACSL1: Acyl-CoA synthetase long-chain family member 1; ACSS1: Acyl-COA synthetase short-chain family member 1; ACSS2: Acyl-CoA synthetase short-chain family member 2; AGPAT: Acyl glycerol phosphate acyl transferase; CD36: Cluster of differentiation 36; CVD: Cardiovascular disease; DGAT: Diacylglycerol acyltransferase; DHA: Docosahexaenoic acid; EPA: Eico-sapentaenoic acid; FABP3: Fatty acids binding protein 3; FABP4: Fatty acids binding protein 4; FADS2: Fatty acid desaturase 2; FAS: Fatty acid synthase; GPAT: Glycerol-3 phosphate acyl transferase; LDLR: Low density lipoprotein receptor;

LPL: Lipoprotein lipase; MUFA: Monounsaturated fatty acid; PPARY: Peroxisome proliferator activated receptor gamma;

PUFA: Polyunsaturated fatty acid; SARA: Subacute ruminal acidosis; SCD: Stearoyl-CoA desaturase; SCFA: Short chain fatty acid; SFA: Saturated fatty acid; UFA: Unsaturated fatty acid

\section{Acknowledgements}

The authors thank the National Nature Science Foundation of China (project no. 31572433), the National Key Research and Development Program of China (2016YFD0501203), the Program for New Century Excellent Talents in University (NCET-13-0862) and the Priority Academic Program Development of Jiangsu Higher Education Institutions (PAPD) for supporting this study.

\section{Funding}

The design of the study and collection, analysis, and interpretation of data were supported by the National Nature Science Foundation of China (project no. 31572433) and the National Key R \& D Program (2016YFD0501203), the Program for New Century Excellent Talents in University (NCET-13-0862) and the Priority Academic Program Development of Jiangsu Higher Education Institutions (PAPD).

\section{Availability of data and materials}

Data sharing not applicable to this article as no datasets were generated or analyzed during the current study.

\section{Authors' contributions}

PT: performed the experiment and drafted the manuscript. $Y L$ and $X L$ : performed the experiment and analyzed the data. YN and RZ: contributed in experiment design and manuscript revision. JT and ST: carried out milk fatty 
acids analysis. $\mathrm{CH}$ and YG: conceived the idea, designed the experiment, and finalized the manuscript. All authors read and approved the final manuscript.

\section{Ethics approval and consent to participate}

The Institutional Animal Care and Use Committee (IACUC) of Nanjing Agricultural University approved all animal procedures. The "Guidelines on Ethical Treatment of Experimental Animals" (2006) No. Three hundred ninety eight by the Ministry of Science and Technology, "China and the Regulation regarding the Management and Treatment of Experimental Animals" (2008) No. Forty five by the Jiangsu Provincial People's Government, was be strictly followed during the slaughter and sampling procedures.

\section{Consent for publication}

Not applicable.

\section{Competing interests}

The authors declare that they have no competing interests.

\section{Author details}

Key Laboratory of Animal Physiology \& Biochemistry, Nanjing Agricultural University, Nanjing 210095, People's Republic of China. ${ }^{2}$ College of Veterinary Medicine, Northwest A and F University, Yangling, Shannxi, China.

\section{Received: 6 March 2017 Accepted: 14 August 2017}

\section{Published online: 01 October 2017}

\section{References}

1. Lock AL, Bauman DE. Modifying milk fat composition of dairy cows to enhance fatty acids beneficial to human health. Lipids. 2004;39:1197-206.

2. Toral PG, Chilliard Y, Rouel J, Leskinen H, Shingfield KJ, Bernard L. Comparison of the nutritional regulation of milk fat secretion and composition in cows and goats. J Dairy Sci. 2015;98:7277-97.

3. Joyce T, Wallace AJ, McCarthy SN, Gibney MJ. Intakes of total fat, saturated, monounsaturated and polyunsaturated fatty acids in Irish children, teenagers and adults. Public Health Nutr. 2009;12:156-65.

4. Diaz-Lopez A, Babio N, Martinez-Gonzalez MA, Corella D, Amor AJ, Fitó M, et al. Mediterranean diet, retinopathy, nephropathy, and microvascular diabetes complications: a post hoc analysis of a randomized trial. Diabetes Care. 2015;38:2134-41.

5. Fritsche K. Fatty acids as modulators of the immune response. Annu Rev Nutr. 2006:26:45-73.

6. Ghazal S, Berthelot V, Friggens NC, Schmidely P. Effects of conjugated linoleic acid supplementation and feeding level on dairy performance, milk fatty acid composition, and body fat changes in mid-lactation goats. J Dairy Sci. 2014:97(11):7162-74.

7. Abo El-Nor SA, Khattab MS. Enrichment of milk with conjugated linoleic acid by supplementing diets with fish and sunflower oil. Pak J Biol Sci. 2012;15(14):690-3

8. Min BR, Hart SP, Sahlu T, Satter LD. The effect of diets on milk production and composition, and on lactation curves in pastured dairy goats. J Dairy Sci. 2005:88:2604-15.

9. Jensen RG, Ferris AM, Lammi-Keefe CJ. The composition of milk fat. J Dairy Sci. 1991;74(9):3228-43.

10. Suburu J, Shi L, Wu J, Wang S, Samuel M, Thomas MJ, et al. Fatty acid synthase is required for mammary gland development and milk production during lactation. Am J Physiol Endocrinol Metab. 2014;306:E1132-43.

11. Bernard L, Leroux C, Chilliard Y. Expression and nutritional regulation of lipogenic genes in the ruminant lactating mammary gland. Adv Exp Med Biol. 2008;606:67-108.

12. Belyea RL, Adams MW. Energy and nitrogen utilization of high versus low producing dairy cows. J Dairy Sci. 1990;73:1023-30.

13. Palmquist DL, Beaulieu AD, Barbano DM. Feed and animal factors influencing milk fat composition. J Dairy Sci. 1993;76:1753-71.

14. Christie WW. The composition, structure and function of lipids in the tissues of ruminant animals. Prog Lipid Res. 1978;17:111-205.

15. Auldist MJ, Walsh BJ, Thomson NA. Seasonal and lactational influences on bovine milk composition in New Zealand. J Dairy Res. 1998:65:401-11.

16. Garnsworthy PC, Masson LL, Lock AL, Mottram TT. Variation of milk citrate with stage of lactation and de novo fatty acid synthesis in dairy cows. J Dairy Sci. 2006;89:1604-12.
17. Kay JK, Weber WJ, Moore CE, Bauman DE, Hansen LB, Chester-Jones H, et al. Effects of week of lactation and genetic selection for milk yield on milk fatty acid composition in Holstein cows. J Dairy Sci. 2005;88:3886-93.

18. Nantapo CTW, Muchenje V, Hugo A. Atherogenicity index and healthrelated fatty acids in different stages of lactation from Friesian, Jersey and Friesian $\mathrm{x}$ Jersey cross cow milk under a pasture-based dairy system. Food Chem. 2014;146:127-33.

19. Steele MA, Alzahal O, Walpole ME, McBride BW. Short communication: grain-induced subacute ruminal acidosis is associated with the differential expression of insulin-like growth factor-binding proteins in rumen papillae of lactating dairy cattle. J Dairy Sci. 2012;95:6072-6.

20. Benchaar C, Lettat A, Hassanat F, Yang WZ, Forster RJ, Petit HV, et al. Eugenol for dairy cows fed low or high concentrate diets: effects on digestion, ruminal fermentation characteristics, rumen microbial populations and milk fatty acid profile. Anim Feed Sci Tech. 2012;178:139-50.

21. Ci L, Liu ZQ, Guo J, Sun HL, Huang YP, Zhao RQ, et al. The influence of maternal dietary fat on the fatty acid composition and lipid metabolism in the subcutaneous fat of progeny pigs. Meat Sci. 2015;108:82-7.

22. Livak KJ, Schmittgen TD. Analysis of relative gene expression data using real-time quantitative PCR and the 2 (-Delta Delta C (T)) method. Methods. 2001;25:402-8.

23. Keunen JE, Plaizier JC, Kyriazakis L, Duffield TF, Widowski TM, Lindinger MI, et al. Effects of a subacute ruminal acidosis model on the diet selection of dairy cows. J Dairy Sci. 2002;85:3304-13.

24. Kleen JL, Hooijer GA, Rehage J, Noordhuizen JP. Subacute ruminal acidosis (SARA): a review. J Vet Med A Physiol Pathol Clin Med. 2003;50:406-14.

25. Gozho GN, Plaizier JC, Krause DO, Kennedy AD, Wittenberg KM. Subacute ruminal acidosis induces ruminal lipopolysaccharide endotoxin release and triggers an inflammatory response. J Dairy Sci. 2005;88:1399-403.

26. Khafipour E, Krause DO, Plaizier JC. Alfalfa pellet-induced subacute ruminal acidosis in dairy cows increases bacterial endotoxin in the rumen without causing inflammation. J Dairy Sci. 2009;92:1712-24

27. Guo Y, Wang L, Zou Y, Xu X, Li S, Cao Z, et al. Changes in ruminal fermentation, milk performance and milk fatty acid profile in dairy cows with subacute ruminal acidosis and its regulation with pelleted beet pulp. Arch Anim Nutr. 2013;67:433-47.

28. Gott PN, Hogan JS, Weiss WP. Effects of various starch feeding regimens on responses of dairy cows to intramammary lipopolysaccharide infusion. J Dairy Sci. 2015;98:1786-96.

29. Haug A, Hostmark AT, Harstad OM. Bovine milk in human nutrition-a review. Lipids Health Dis. 2007:6:25

30. Dewhurst RJ, Shingfield KJ, Lee MRF, Scollan ND. Increasing the concentrations of beneficial polyunsaturated fatty acids in milk produced by dairy cows in high-forage systems. Anim Feed Sci Tech. 2006;131:168-206.

31. Williams CM. Dietary fatty acids and human health. Ann Zootech 2000;49:0-44.

32. Chilliard Y, Glasser F, Ferlay A, Bernard L, Rouel J, Doreau M. Diet, rumen biohydrogenation and nutritional quality of cow and goat milk fat. Eur J Lipid Sci Technol. 2007:109:828-55.

33. Gao X, Oba M. Short communication: noninvasive indicators to identify lactating dairy cows with a greater risk of subacute rumen acidosis. J Dairy Sci. 2015;98:5735-9.

34. Tao $H$, Chang $G$, Xu T, Zhao $H$, Zhang $K$, Shen XZ, et al. Feeding a high concentrate diet down-regulates expression of ACACA, LPL and SCD and modifies milk composition in lactating goats. PLoS One. 2015:10:e0130525.

35. Bionaz M, Loor JJ. Gene networks driving bovine milk fat synthesis during the lactation cycle. BMC Genomics. 2008:9:366.

36. Fielding BA, Frayn KN. Lipoprotein lipase and the disposition of dietary fatty acids. Br J Nutr. 1998:80:495-502.

37. Zhu J, Sun Y, Luo J, Wu M, Li J, Cao Y, et al. Specificity protein 1 regulates gene expression related to fatty acid metabolism in goat mammary epithelial cells. Int J Mol Sci. 2015;16:1806-20.

38. Oppi-Williams C, Suagee JK, Corl BA. Regulation of lipid synthesis by liver $X$ receptor alpha and sterol regulatory element-binding protein 1 in mammary epithelial cells. J Dairy Sci. 2013;96:112-21.

39. Yao D, Luo J, He Q, Shi H, Li J, Wang H, et al. SCD1 alters long-chain fatty acid (LCFA) composition and its expression is directly regulated by SREBP-1 and PPARgamma 1 in dairy goat mammary cells. J Cell Physiol. 2016;232:635-49.

40. Xu HF, Luo J, Zhao WS, Yang YC, Tian HB, Bionaz M, et al. Overexpression of SREBP1 (sterol regulatory element binding protein 1) promotes de novo fatty acid synthesis and triacylglycerol accumulation in goat mammary epithelial cells. J Dairy Sci. 2016;99:783-95. 
41. Harvatine KJ, Boisclair YR, Bauman DE. Recent advances in the regulation of milk fat synthesis. Animal. 2009;3:40-54.

42. Bauman DE, Harvatine KJ, Lock AL. Nutrigenomics, rumen-derived bioactive fatty acids, and the regulation of milk fat synthesis. Annu Rev Nutr. 2011;31:299-319.

43. Martin DB, Horning MG, Vagelos PR. Fatty acid synthesis in adipose tissue. I. Purification and properties of a long chain fatty acid-synthesizing system. J Biol Chem. 1961;236:663-8.

44. Cohen P, Ntambi JM, Friedman JM. Stearoyl-CoA desaturase-1 and the metabolic syndrome. Curr Drug Targets Immune Endocr Metabol Disord. 2003;:3:271-80

45. Enoch HG, Catala A, Strittmatter P. Mechanism of rat liver microsomal stearyl-CoA desaturase. Studies of the substrate specificity, enzyme-substrate interactions, and the function of lipid. J Biol Chem. 1976;251:5095-103.

46. Mashek DG, Coleman RA. Cellular fatty acid uptake: the contribution of metabolism. Curr Opin Lipidol. 2006;17:274-8.

47. Ma L, Corl BA. Transcriptional regulation of lipid synthesis in bovine mammary epithelial cells by sterol regulatory element binding protein-1. J Dairy Sci. 2012;95:3743-55.

48. Bionaz M, Loor JJ. ACSL1, AGPAT6, FABP3, LPIN1, and SLC27A6 are the most abundant isoforms in bovine mammary tissue and their expression is affected by stage of lactation. J Nutr. 2008:138:1019-24.

49. Barber MC, Clegg RA, Travers MT, Vernon RG. Lipid metabolism in the lactating mammary gland. Biochim Biophys Acta. 1997;1347:101-26.

50. Shi HB, Zhao WS, Luo J, Yao DW, Sun YT, Li J, et al. Peroxisome proliferatoractivated receptor gamma1 and gamma2 isoforms alter lipogenic gene networks in goat mammary epithelial cells to different extents. J Dairy Sci. 2014;97:5437-47.

51. Fujino T, Kondo J, Ishikawa M, Morikawa K, Yamamoto TT. Acetyl-CoA synthetase 2, a mitochondrial matrix enzyme involved in the oxidation of acetate. J Biol Chem. 2001;276:11420-6.

52. Singh K, Molenaar AJ, Swanson KM, Gudex B, Arias JA, Erdman RA, et al. Epigenetics: a possible role in acute and transgenerational regulation of dairy cow milk production. Animal. 2012;6:375-81.

53. Jaenisch R, Bird A. Epigenetic regulation of gene expression: how the genome integrates intrinsic and environmental signals. Nat Genet. 2003:33(Suppl):245-54.

54. Dong G, Qiu M, Ao C, Zhou J, Khas E, Wang X, et al. Feeding a highconcentrate corn straw diet induced epigenetic alterations in the mammary tissue of dairy cows. PLoS One. 2014;9:e107659.

\section{Submit your next manuscript to BioMed Central and we will help you at every step:}

- We accept pre-submission inquiries

- Our selector tool helps you to find the most relevant journal

- We provide round the clock customer support

- Convenient online submission

- Thorough peer review

- Inclusion in PubMed and all major indexing services

- Maximum visibility for your research

Submit your manuscript at www biomedcentral.com/submit

) Biomed Central 